\title{
Images of Society
}

\section{Essays on the Sociological Theories of Tocqueville, Marx, and Durkheim}

Gianfranco Poggi. This volume investigates aspects of the sociological theories of Tocqueville, Marx, and Durkheim that have not previously been explored in detail. Through an interpretive reading of selected writings, the author shows how these ideas can make a substantial contribution to contemporary sociological theory.

$\$ 8.95$

\section{Every Fifth Child}

\section{The Population of China}

Leo $A$. Orleans. This work attempts to tell the story of China's population: a little about what it was, but mostly about what it is and what we know and don't know about it. The result is the most comprehensive and up-to-date analysis of China's massive population problems, focusing on areas where policy and daily life coincide: the schools, farms, and factories. $\$ 8.50$

\section{Language in Sociocultural Change}

\section{Essays by Joshua A. Fishman}

Selected by Anwar S. Dil. Sociocultural change is viewed by the author as the most fitting context in which to consider language in society. These papers demonstrate the importance of language-related concerns for modern social science and cover such topics as language maintenance and shift, societal bilingualism, the sociology of language, and language planning. \$10.00

\section{Stanford University Press}




\section{SURVEY}

\section{A Journal of East and West Studies}

\section{Volume 18 No. $3(84)$}

Summer 1972

\section{EUROPE TODAY}

Arrigo Levi

F. Stephen Larrabee

\section{INTERNATIONAL COMMUNISM}

Theodore Draper

Philip J. Jaffe

\section{REVOLUTION}

Manès Sperber

Tibor Szamuely
Lewis $S$. Feuer

Heinz Schurer

\section{SAMIZDAT}

Political Diary

Andrei D. Sakharov

Annual subscription $\varepsilon_{3}$ or US $\$ 8$

Student subscription $£_{1} \cdot 50$ or US $\$ 4$

Single copies: 75P or US $\$ 2$

Editorial office: llford House, 133 Oxford Street, London W I R ITD Subscription office: Oxford University Press, Press Road, Neasden, London NW 10 oDD 


\title{
Sugar Without Slaves
}

The Political Economy of British Guiana, 1838-1904

\section{by Alan H. Adamson}

Sugar Without Slaves is a study of the wide range of problems confronting a multiracial, multicultural, one-crop British colony in the post-emancipation nineteenth century. Its principal themes have to do with the survival of sugar as the dominant crop, of the plantation economy as the dominant system of production, and of the sugar planters as the dominant social and political group. Most of the data are from primary sources and the evidence is new and voluminous. Historians and social scientists alike will find here fascinating insights into the complex network of social and economic relations that developed in this Caribbean country a century ago and have a clear bearing on the tensions besetting Guyanese society today.

\section{The Dimensions of the Past}

\author{
Materials, Problems, and Opportunities for Quantitative Work in \\ History \\ edited by Val R. Lorwin and Jacob M. Price
}

The thirteen papers in this innovative collection were designed to increase awareness in the historical profession of the possibilities and problems of quantitative work in fields other than U.S. history. The contributors, all leading figures in their fields, confronted four major issues: the kinds of quantitative data available for the problems, periods, and areas under discussion; the chief uses already made of these data; the most important problems in utilizing such data; and the most promising directions for further work, both substantive and methodological. As a result, this volume provides a remarkably wide bibliographical, methodological, and critical guide to current quantitative work in European, Asian, and Latin American History.

\section{Economic Opportunity and White American Fertility Ratios, 1800-1860

\author{
by Colin Forster and G. S. L. Tucker
}

The role of economic factors in fertility behavior has attracted growing interest among economists, historians, economic historians, and demographers. The point of departure for this new study is the discussion of population density as an important causal factor in fertility patterns in Yasukichi Yasuba's Birth Rates of the White Population in the United States, 1800-1860. Forster and Tucker shift the statistical analysis of the census data from rank correlations by state, which Yasuba had done, to more refined regression analysis. In doing so, they show much more clearly than anyone else has yet shown that high fertility ratios were related to the thinness of settlement.

$\$ 6.50$

\section{World Handbook of Political and Social Indicators}

\section{second edition}

\section{by Charles L. Taylor and Michael C. Hudson}

This new, completely revised edition of the World Handbook is one of the most complete collections of cross-national attribute and event data available to scholars of comparative and international politics. Included are series measuring political performance and structure, aspects of external relations, economic development and differentiation, demographic characteristics, and other social phenomena for the 136 countries which had one million or more population in 1965 or were members of the UN by 1968 . Mr. Taylor discusses the analysis of the data and suggests uses to be made of them in the final chapter of the book.

\section{Y A Yale University Press New Haven and London \\ L $\mathbf{E}$ in Canada : McGill-Queen's University Press}




\section{ANNALES}

Économies - Sociétés - Civilisations

Revue bimestrielle, fondée en 1929 par Lucien FEBVRE et Marc BLOCH Comité de direction: Fernand BRAUDEL, Marc FERRO, Georges FRIEDMANN, Jacques LE GOFF, Emmanuel LE ROY LADURIE, Charles MORAZE

Secrétaire du Comité: Paul LEUILLIOT

Secrétaire de la Rédaction: André BURGUIERE

27e ANNÉE-No. 4-5

JUILLET-OCTOBRE 1972 NUMERO SPECIAL, "FAMILLE ET SOCIETTE".

\section{SYSTEMES FAMILIAUX}

G. DUBY Lignage, noblesse et chevalerie au XIIe siècle dans la région mâconnaise

E. LE ROY LADURIE Pour une anthropologie structurale de la France d'Ancien Régime

P. LASLETT La famille et le ménage: approches historiques

Ch. KLAPISCH "A uno pane e uno vino": la famille rurale toscane (début du XVe sièle)

W. KULA La seigneurie et la famille paysanne

D. SABEAN Famille et tenure paysanne: aux origines de la Guerre des Paysans en Allemagne

A. COLLOMP Famille nucléaire et famille élargie en Haute-Provence au XVIIIe siècle

M. BAULANT La famille en miettes: sur un aspect de la démographie du XVIIe siècle

J. CUISENIER Parenté et organisation sociale dans le domaine turc

FAMILLES EN FICHES

L. HENRY La fécondité des mariages dans le quart Sud-Ouest de la France, de 1720 à 1829 (II)

J. DUPÂQUIER La dimension théorique de la famille. Ce qui fait les familles nombreuses

Y. DAUBEZE et J. C. PERROT Un programme d'étude démographique sur ordinateur

A. SCHOFIELD La reconstition des familles par ordinateur: un exemple anglais ?

A. CHAMOUX La reconstitution des familles: espoirs et réalités

NORMES ET DEVIANCES

P. BOURDIEU Les stratégies matrimoniales dans le système des stratégies de reproduction

E. ORTIGUES La psychanalyse et les institutions familiales

A. BURGUIERE Le mariage tardif et l'esprit d'entreprise

J. M. GOUESSE Parenté, famille et mariage en Normandie aux XVIIe et XVIIIe siècle

F. LEBRUN Naissances illégitimes et abandons d'enfants en Anjou au XVIIIe siècle

J. DEPAUW Amour illégitime et société à Nantes au XVIIIe siècle

H. G. GUTMAN Le phénomène invisible. La composition de la famille et du foyer noir après la Guerre de Sécession

F. LAUTMANN Pour une sociologie de l'organisation familiale

COMPTES RENDUS Démographie et Sociologie de la famille

Rédaction: 54, boulevard Raspail, Paris-VI' (222-23-49)

Administration: Librairie Armand COLIN, ro3, boulevard Saint-Michel, Paris-V ${ }^{\circ}$ Comptes chèques postaux: PARIS, $\mathrm{N}^{\circ} 21335-25$

Abonnements: France et Union Française : 43 F-Etranger: $60 \mathrm{~F}$

Le numéro: $8 \mathrm{~F}$ - Numéros spéciaux: $18 \mathrm{~F}$ 


\section{THE WORLD TODAY}

The monthly journal of the Royal Institute of International Affairs provides the general reader with up-to-date and authoritative information on current world problems.

The September 1972 issue contains the following articles:

PROSPECTS FOR MONETARY REFORM by Ian Davidson THE TACTICAL AIR BALANCE IN EUROPE by Neville Brown ICELAND, EUROPE, AND NATO by Ake Sparring SADAT AND THE SOVIET UNION by Anthony McDermott WAS UNCTAD III A FAILURE? by Vanya Walker-Leigh

Annual Subscription: $£ 3.25$ post free (USA and Canada \$10). 28p per copy.

Orders may be sent to booksellers and newsagents, or to the OXFORD UNIVERSITY PRESS, Press Road, Neasden, London, NW10 ODD (Tel. 01-450 8080). 
Comparative Studies in Society and History is a forum for presentation and discussion of new research into problems of change and stability that recur in human societies through time or in the contemporary world. It sets up a working alliance between specialists in all branches of the social sciences and humanities. Debate and review articles bring the general reader in touch with current findings and issues.

\section{NOTES FOR CONTRIBUTORS}

Contributions may be descriptive, analytical or theoretical. Any article not in itself comparative may be accepted if it lends itself to comment that will place it in comparative perspective. Correspondence with the editors prior to the submission of articles will help to enable them to obtain such comment or a companion study. Emphasis in comparative studies may be either on similarities or, if these are significant enough and call for some recasting of generalisations, on differences. All contributions and editorial correspondence should be sent to the Editors, Comparative Studies in Society and History, Department of History, University of Michigan, Ann Arbor, Michigan 48104.

Two copies of each contribution, preferably accompanied by a stamped, addressed envelope, should be submitted. Both text and footnotes should be clearly typed with double spacing and wide margins; footnotes should appear on separate pages at the end of the article. Illustrations may be included by arrangement with the editors.

Contributors will receive 50 offprints bound in the journal covers. Any additional offprints must be ordered on receipt of the first proof. 


\section{COMPARATIVE STUDIES IN SOCIETY AND HISTORY}

Editorial Foreword

\section{Inheritance}

JACK GOoDY Strategies of Heirship

Cities

Ira M. LApidus The Early Evolution of Muslim Urban Society

Clifton K. Yearley The 'Provincial Party' and the Megalopolises: London, Paris, and New York, 1850-1910

\section{Folk Saints}

Barbara Jane Macklin and N. Ross Crumrine Three North Mexican Folk Saint Movements

William A. Christian. JR. Holy People in Peasant Europe 106-114

\section{Assimilation}

Song Nai RheE Jewish Assimilation: The Case of Chinese Jews

(C) Society for the Comparative Study of Society and History, 1973

\section{Cambridge University Press}

Bentley House, 200 Euston Road, London NW1 2DB American Branch: 32 East 57th Street, New York, N.Y. 10022

$$
£ 2.00 \text { net in U.K.; } \$ 5.00 \text { in U.S.A. }
$$

Subscription price $£ 5.00$ net in U.K.; $\$ 14.00$ in U.S.A. 